\title{
Erfaringer med brug af multimediecases
}

\section{Rikke N. Ørngreen}

Copenhagen Business School, Handelshøjskolen

orngreen@cbs.dk

http://www.cbs.dk/staff/orngreen

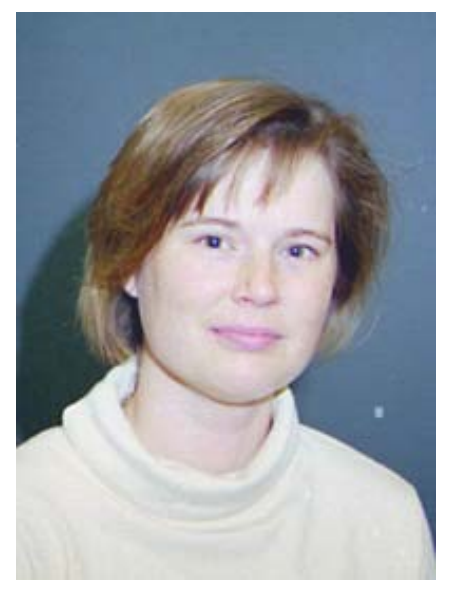

Rikke Ørngreen er adjunkt ved Institut for Informatik (http://www.inf.cbs.dk), CBS, og tilknyttet HCI-Research Group (http://asp.cbs.dk/hci/home.html).

Casebaseret undervisning har ligesom mange andre undervisningsformer fundet vej til de digitale, multimediale og virtuelle rum. Denne artikel beskæftiger sig med under-

visningscases, der både er baseret på IKT-teknologier, i dette tilfælde webbaserede cases, og som er multimediale, dvs. gør brug af flere asynkrone og synkrone medieformer. Casene anvendes i dag primært som undervisningsmateriale i forbindelse med tilstedeværelsesundervisning, men bruges også i helt virtuelle online-forløb. Jeg har i forbindelse med et større forskningsprojekt haft mulighed for at undersøge, hvad det særegne såvel som de kritiske punkter er ved undervisning med multimedie- og webbaserede cases på merkantile uddannelser. (Herefter betegnes disse cases for nemheds skyld som multimediecases eller blot cases, hvor det specifikt af sammenhængen fremgår, at det drejer sig om multimediecases.)

Jeg vil i artiklen pege på områder, som kræver opmærksomhed under brug og udvikling af multimediecases, og jeg ser på, hvordan en sådan undervisning kan gennemføres. Herunder gennemgår jeg nogle forslag til værktøjer, som kan anvendes for at opnå en læringsproces, hvor de studerende er engagerede i undervisningen, og hvor de aktiveres til et højt refleksionsniveau, der både inddrager praksis fra casen, og som er funderet i fagets teori.

\section{E-case serien}

Figur 1 viser et eksempel på et skærmbillede fra den multimediecase-serie, som jeg har undersøgt. Skærmbilledet er fra E-case-serien, og casen om casevirksomheden Rockwool A/S. E-case serien er udviklet i EU-projektet BUSINES-LINC (Business Innovation Networks - Learning with Interactive Cases). Fælles for casene er, at de beskæftiger sig med emnet $e$-handel. Mere information om projektet fås i Orngreen 2002. Her beskriver jeg blot lidt om de cases, der blev udviklet på $\mathrm{CBS}$, for at give en fornemmelse for deres mål, omfang, funktionalitet, design og interaktionsform. 
Casene lægger ikke i sig selv op til dialog mellem studerende, forstået således, at de ikke indeholder nogen former for kommunikationsværktøjer. Ligesom med papirbaserede cases skal disse multimediecases altså anvendes enten på traditionel vis ved fysisk tilstedeværelse, eller vha. standard-IKT-værktøjer, som fx. studiets LMS (Learning Management System).

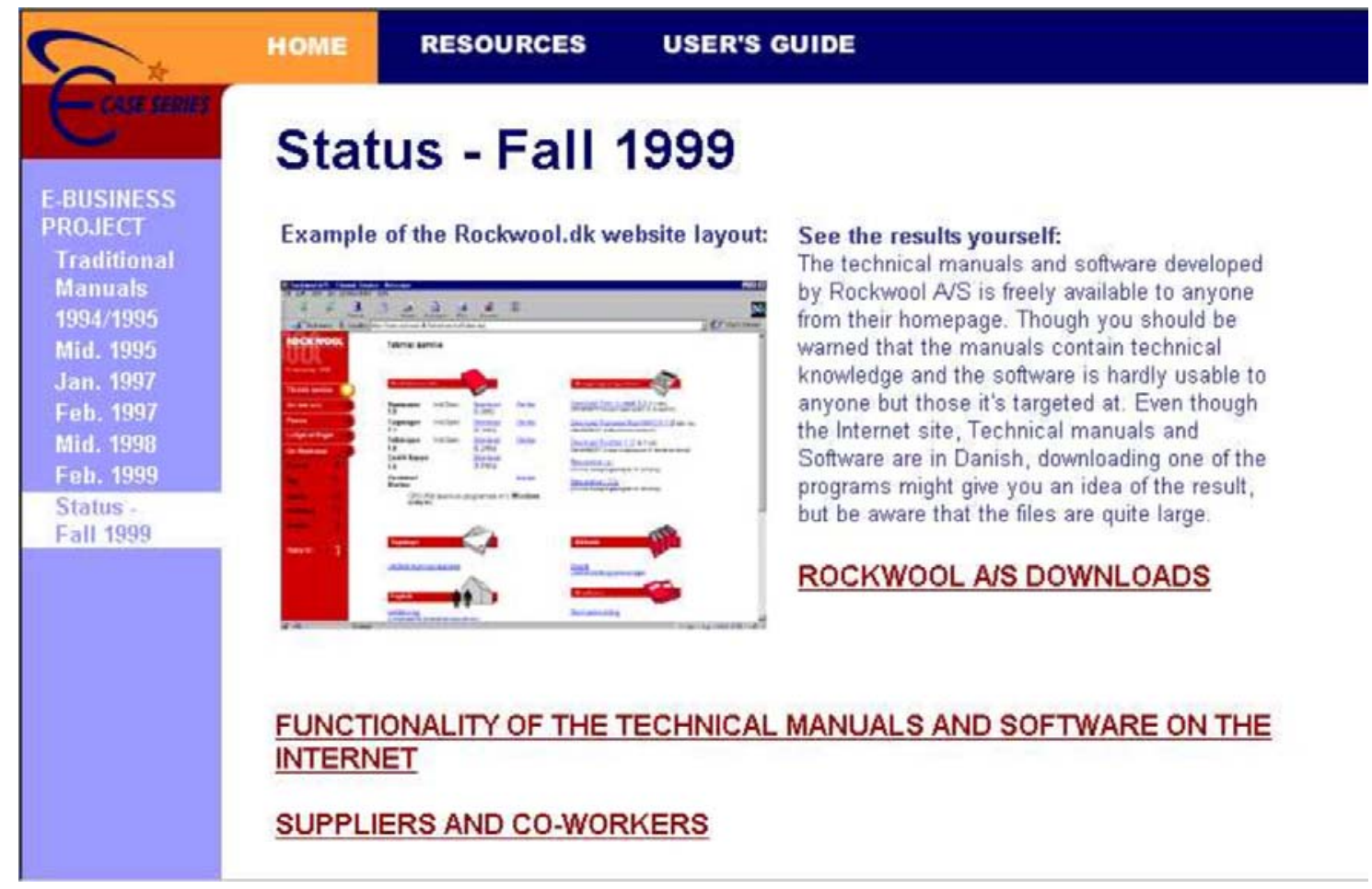

Figur 1

Casene kører i en web-browser, og navigeringen er derfor forholdsvis "nem" for langt de fleste net-vante studerende. Casene er HTML-baserede og sælges på CD-ROM med licens til pc'er / Windows-servere. Generelt anvendes flere typer af medier i casene: tekst og tabeller, grafiske animationer, videoclips af personer fra virksomheden, illustrationer og/eller billeder.

I alle de tre danske cases er der endvidere brugt stemmer fra professionelle skuespillere. De enten præsenterer virksomheden og materialet, dvs. fungerer som oplæser, eller de spiller en rolle i casen (som fx medarbejder, se tabel 1). Hyperlinks anvendes i vid udstrækning i alle cases, både internt i den enkelte case, og også eksternt til links videre ud i verden, til casevirksomhedens egen hjemmeside, til konkurrenter, til nyhedssider mv.

Hver af de danske cases har en introduktionssekvens, hvorefter de studerende har mulighed for at navigere rundt $i$ en menustruktur, men casenes design, form og struktur varierer, grundet forskellige læringsmål / budskaber. Tabel 1 beskriver de tre cases. Skærmbillederne i figur 2 illustrerer vha. casen om LEGO Gruppen, hvordan de forskellige medier anvendes. Hovedmenuen er konsulentens midlertidige kontor, hvor forskellige afdelingsmapper og mv. kan undersøges. Afdelingsmapperne indeholder rapporter, som de to næste billeder er eksempler på. Det sidste billede viser et af de fire iscenesatte interviews. 


\begin{tabular}{|c|c|}
\hline g indhold & \\
\hline $\begin{array}{l}\text { "The ALKA Teaching Case-BPR in the } \\
\text { Insurance Sector" præsenterer forsikrings- } \\
\text { selskabet ALKA A/S, som har været gen- } \\
\text { nem et BPR-projekt (Business Process Re- } \\
\text { engineering). I dette projekt har ALKA } \\
\text { substitueret deres traditionelle salgsstyrke } \\
\text { og papirbaserede klageprocesser med ar- } \\
\text { bejdsgange, der gør brug af en kombinati- } \\
\text { on af telekommunikation og IT. }\end{array}$ & $\begin{array}{l}\text { Casen beskriver BPR-projektet samtidig med, } \\
\text { at en analyse af projektets konsekvenser gi- } \\
\text { ves. En oplæser introducerer casen og som } \\
\text { præsenterer emner, uddyber og forklarer en } \\
\text { række animationer etc. Menuen giver en fag- } \\
\text { lig/emnemæssig opdeling, som i introduktio- } \\
\text { nen foreslås brugt i en bestemt rækkefølge, } \\
\text { der har interesse kronologisk set. Der er video } \\
\text { og tekstcitater taget fra interviews med to } \\
\text { ledere i ALKA. }\end{array}$ \\
\hline $\begin{array}{l}\text { "The LEGO Teaching Cas } \\
\text { sumer Access" behandler } \\
\text { overvejes i forbindelse me } \\
\text { salg, marketing og brandi } \\
\text { på internettet. Casen foku, } \\
\text { linger: den ene er ansvarli } \\
\text { delse af marketing/brandi } \\
\text { ningssiderne lego.com, og } \\
\text { ansvarlig for internetbutik }\end{array}$ & $\begin{array}{l}\text { Brugeren af casen får at vide, at han/hun nu er } \\
\text { en ekstern konsulent, som skal evaluere det } \\
\text { hidtidige arbejde i de to afdelinger, og på } \\
\text { baggrund af dette udvikle strategier for frem- } \\
\text { tiden. Casematerialet gives i en menustruktur, } \\
\text { hvor hovedmenuen er konsulentens midlerti- } \\
\text { dige kontor. } \\
\text { Der er pre-formulerede spørgsmål, som bru- } \\
\text { geren i rollen som konsulenten kan stille til } \\
\text { fire ledere i LEGO. Svar gives som video } \\
\text { eller lydklip, eller som et tekstcitat. Der er } \\
\text { også brugt en fortæller. }\end{array}$ \\
\hline $\begin{array}{l}\text { "The Rockwool Teaching Case - E- } \\
\text { Business \& Customer Relations" illustrer } \\
\text { den rolle e-services kan have ved at præ- } \\
\text { sentere CRM (Customer Relations Mana- } \\
\text { gement) initiativer implementeret på den } \\
\text { danske isoleringsvirksomhed, Rockwool } \\
\text { A/S hjemmeside. Rockwools sider infor- } \\
\text { merer kunder om byggeregulativer ift. } \\
\text { brand mv., og indeholder softwareværkte } \\
\text { jer, der kan støtte kunderne i at lave udre } \\
\text { ninger, således at rette isoleringsmængde }\end{array}$ & $\begin{array}{l}\text { onen fortæller "en Rockwool- } \\
\text { ugeren nu er en ny medarbejder i } \\
\text { rojektet. Projektet skal evalueres, } \\
\text { tningsplan skal afleveres. Der er en } \\
\text { denne forretningsplan med en } \\
\text { skrifter, som kan udfyldes. Der } \\
\text { t to roller, en er "gammel" projekt- } \\
\text { anden salgskonsulent. Rollernes } \\
\text { s både som lyd (skuespiller) og } \\
\text { begge er baseret på faktiske inter- }\end{array}$ \\
\hline
\end{tabular}

Tabel 1 


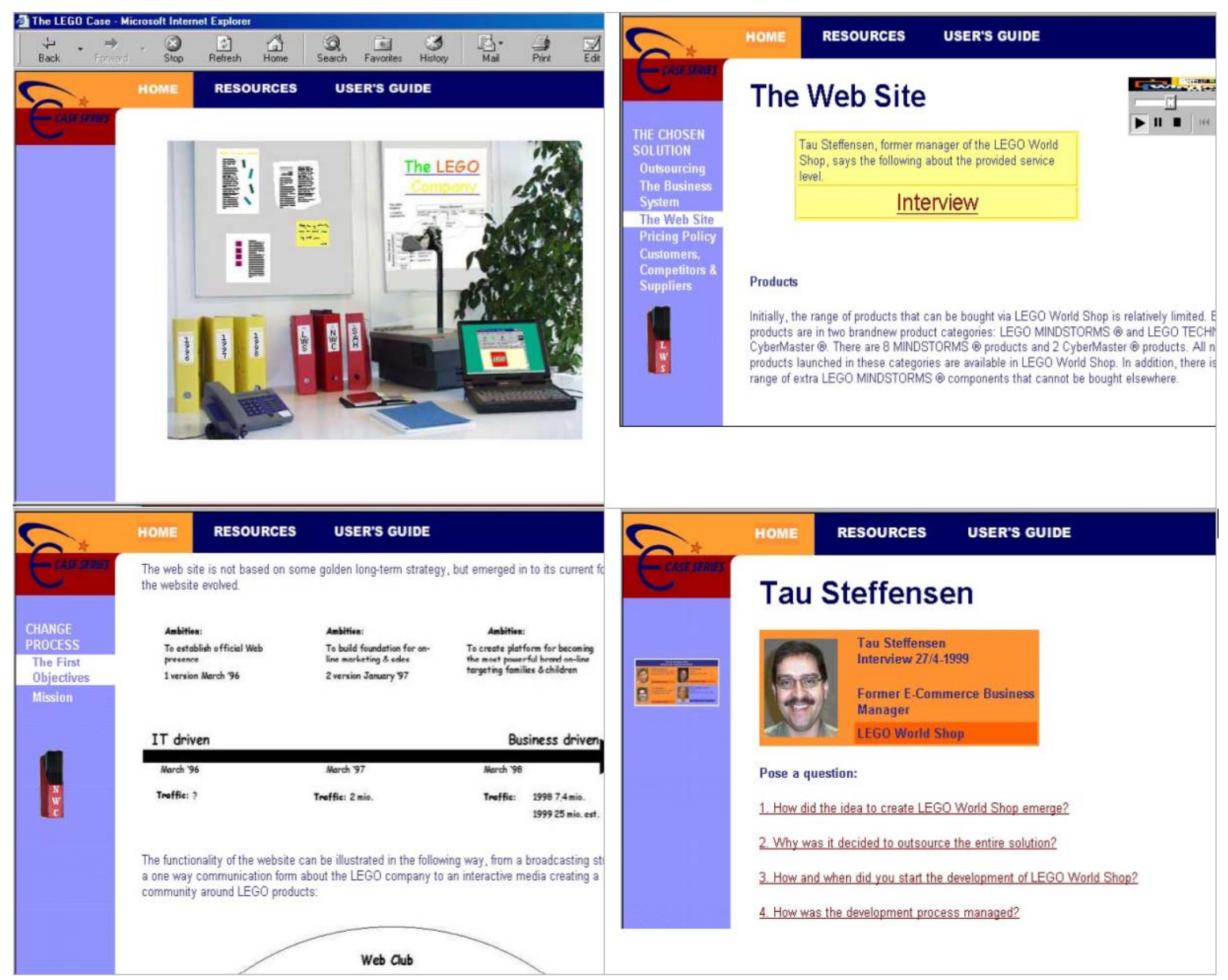

Figur 2

Generelt set bruges cases for at øge de studerendes forståelse af situationers kompleksitet og for at bringe erfaringer fra virkeligheden ind i undervisningen. Mere specifikt er læringsmålet at sætte de studerende i stand til at analysere en hændelse, finde frem til de væsentlige informationer, evaluere det mulige handlerum, og dernæst træffe en beslutning om: 1) hvad er problemet/muligheden i casen og evt. 2) hvad er den mest hensigtsmæssige løsning i forhold til en række faktorer/variable.

\section{Undersøgelsesdesign}

Forskningsresultaterne i denne artikel stammer fra empiriske studier med cases fra E-caseserien. Mere specifikt drejer det sig om observationer af caseundervisning, videoanalyse af brugssituationer, fokusgruppe- og individuelle interviews med caseundervisere og studenter, skrevne evalueringer fra undervisere og eksperter, samt spørgeskemaundersøgelser. Analyse og indsamling udførte jeg primært ved brug af kognitive etnografiske metoder og teknikker (Ball \& Ormerod 2000; Nielsen et al. 2002).

Formålet med undersøgelserne var at få en mere detaljeret forståelse for, hvad der skal overvejes i forbindelse med udvikling og brug af multimedie- og webbaserede cases. Det var ikke min hensigt at evaluere, om caseundervisning er en bedre eller mere velegnet læringsmodel end andre i forhold til det givne fag, men mere at finde en måde, hvorpå multimediecasenes potentiale kan udnyttes. Jeg tog udgangspunkt $i$ en analyse af casedialogen og de studerendes egen vurdering af arbejde med casen. Primært fordi dialogen er en vigtig del af læringsprocessen, og sekundært fordi underviserne prioriterede casediskussionen i plenum. Jeg vægtede derfor at undersøge dialogen (både i små grupper og i plenum) og niveauet i dialogen for at kunne sige noget om pædagogiske værktøjer, planlægning af undervisningen og struktur (rollefordeling) ved brug af multimediecases. 
For at kunne vurdere niveauet $\mathrm{i}$ dialogen, tog analysen blandt andet udgangspunkt $\mathrm{i}$

Blooms taksonomi med de 6 niveauer: vidensgenkendelse, forståelse, anvendelse, analyse, syntese og evaluering (fra Bloom 1956, part II). Lee argumenterer for, at netop niveauerne er brugbare i analyse af den aktive konstruktion af viden (Lee 1999). Det vil ifølge Lee være muligt at observere, om studerende kan genkende emner fra en case, og denne adfærd kan tolkes som det første skridt i konstruktion af ny viden. Lee ser således Blooms seks undervisningsmål som en proces, studerende gennemgår i konstruktion af viden. Det kan diskuteres, om der altid er tale om en lineær, hierarkisk proces, men for at kunne analysere om casens og underviserens læringsmål var opfyldt, fungerede Blooms taksonomi godt. Set i relation til undervisningscases, deres brug og mål, er det analyseniveauet, der er interessant og undertiden endda syntese- og evalueringsniveauet.

I det følgende har jeg udvalgt nogle enkelte temaer til diskussion.

\section{Motivering og engagement}

Det viste sig, at casediskussionen i plenum ofte foregik med meget lidt aktivitet fra de studerende og på et lavt niveau. Det gav anledning til bekymring, om de studerende ikke fandt casene motiverende nok til, at de ville engagere sig i dem. Det viste sig dog ved interviews og ved kvalitative og kvantitative spørgsmål i spørgeskemaundersøgelsen, at de studerende havde en endog meget positiv oplevelse af casene. Generelt gav observationerne og samtaler med studerende indtryk af, at netop multimediematerialet gav mulighed for større indlevelse og fornemmelse for "den virkelige" verden; det at kunne fornemme en afdelingsleders problemer i et videoklip eller få en opfattelse af en kompliceret proces via en animation. Og i spørgeskemaet havde godt $90 \%$ et positivt svar til spørgsmålet, om budskabet i casens historie var udtrykt på en realistisk måde.

Dog viste det sig, at $21 \%$ samlet set var uenig i, at casen var designet på en forståelig og passende måde. Da de studerendes svar på de kvalitative spørgsmål om samme emne i spørgeskemaundersøgelsen blev undersøgt, kom især en vigtig pointe frem. De studerende var ikke i stand til at abstrahere fra, at der var anvendt såkaldt dummy-medier i lydklippene. Dvs. i nogle af de tidlige versioner var der anvendt en ikke-professionel speaker, optaget med "hjemmegjort" udstyr og ikke - som senere - i et lydstudie med skuespillere. Umiddelbart vurderede den lidt ældre MBA-målgruppe, at casene var lettere at bruge og mere velstrukturerede i mediebrug, end bachelorer og kandidatstuderende. Det kan skyldes, at den yngre generations erfaringer fra meget professionelle produkter, såsom spil og 3d-animationer gør deres kriterier og krav til multimedier er højere end de øvriges. Det virkede i hvert fald under samtalerne som om de lidt "ældre" MBA'ere var mere imponerede end de yngre bachelorer.

At casene overordnet og især i deres endelige version anses som interessante, godt designet osv., kunne også skyldes nyhedsværdien af multimediecases. På den anden side ville langt de fleste anbefale, at sådanne cases blev anvendt igen, også med dem selv som studerende, og langt de fleste følte at casene havde øget deres interesse for emnet. Generelt virkede MBA-studerende mere motiverede, både $\mathrm{i}$ deres engagement $\mathrm{i}$ casene og $\mathrm{i}$ undervisningen. De er måske mere bevidste om, hvorfor de er til stede og mere opsatte på at få noget ud af de ressourcer, de anvender, både økonomisk og tidsmæssigt, i forhold til fuldtidsstuderende.

I mine samtaler med de studerende og i observation af casedialogen, fandt jeg, at nogle typer pædagogiske værktøjer var mere eksplicit motiverende (de studerende sagde direkte, at de oplevede dem som sjove, spændende etc.) og implicit engagerende (de studerende og underviserne henviste til dem i casediskussionen). Dette var de forskellige typer af roller og handlingsorienterede værktøjer, som det at lave en forretningsplan (se casebeskrivelserne i tabel 1). Disse tiltag er inspireret af rollespil og simuleringsapplikationer. 
Undervisningssimulationer, generelt set, sætter fx. en referenceramme for en virtuel virksomhed, hvor en række variable gives. Vel at mærke variable som de studerende kan ændre på, fx. antal indkøbte varer, distributionsmuligheder mv. Det er således i langt højere grad den individuelle (evt. gruppens) brug af selve simulationen, der udgør læreprocessen, nemlig det at handle aktivt, at "lege" med tallenes/variablenes indbyrdes forhold og derigennem få en forståelse for den anvendte model i simulationen. Rollespillene, ligesom simulationerne, fokuserer også på handling i "nuet", men her er det som oftest de kommunikative handlingselementer, der er i fokus.

Det at bruge roller indlejret i caseundervisning er ikke nyt. Caselitteratur anbefaler rollespil som et supplerende pædagogisk værktøj i undervisningen. Hver student (eller gruppe af studenter) bliver tildelt en interessentrolle, som de skal leve sig ind i og spille (Heath 1998). Men det er vigtigt at bruge værktøjerne bevidst, da værktøjerne overordnet set har et andet læringsmål og fokus. Læringsmålet om at kunne handle i et foranderligt miljø her og nu skal ses i relation til undervisningscases, hvor dialog om en virkelig hændelse er den primære del af læreprocessen.

Til slut er det interessant at bemærke, at brug af indlejrede varktøjer - roller og handlingselementer foruden at øge motivation og engagement også gjorde, at de studerende antog et bestemt perspektiv i deres analyse af casen (det ser jeg på senere).

\section{Forberedelsestid og dialog}

Mængden af materiale i multimediecasene er ret stor. Derfor forventede jeg, at de studerende ville bruge minimum to timer på individuel forberedelse, hvis casen blev brugt $i$ en traditionel undervisningssituation. Middelværdien for forberedelse var $170 \mathrm{~min}$ - altså en del over det forventede. Ved nærmere eftersyn viste det sig dog, at den klasse, hvor alle skulle lave en skriftlig rapport, hævede forberedelsestiden (brugte $640 \mathrm{~min}$. i gennemsnit). Hvis de sessioner og grupper, som havde skriftlige opgaver, trækkes fra, var forberedelsestiden langt under de forventede to timer. Fordelingen viste, at over halvdelen faktisk brugte mindre end eller omtrent én time.

Multimediecases tager længere tid at forberede end skrevne cases generelt gør, og skimning er svært. For nogle var den direkte konsekvens heraf at droppe forberedelsen, da det ikke var muligt at forberede sig bare lidt frem for at bruge uforholdsvis meget tid (i deres øjne) set i lyset af, at casen "kun" blev brugt til to lektioners traditionel casediskussion. Fordi så få var forberedte, blev casediskusionen meget "død i sværen", eller i bedste fald var det de samme få, der udtalte sig. Men ved at udvide det traditionelle forløb med pædagogiske værktøjer som opgaver, synopsis, rapporter, mundtlige studenter-gruppepræsentationer, osv., blev de studerende guidet til at anvende en mere effektiv forberedelsesform, og det øgede forberedelsestiden og niveauet af deres analyse/evaluering signifikant. Jeg så også hvordan det styrkede aktiviteten i klassediskussionen.

Jeg fik lov til at følge en række gruppers arbejde med casene, hvor det var blevet "krævet", at de skulle lave en præsentation af et specifikt emne og efterfølgende lede en casediskussion om dette. ("Kræve" i citationstegn, da der ikke var mødepligt, og caseopgaverne ikke indgik i den endelige bedømmelse.) I de gruppesessioner jeg observerede og videooptog, viste det sig, at dialogen foregik på et meget højt niveau, hvor hvert individ bragte sit perspektiv med ind i diskussionen, hvilket gav de andre nye perspektiver til casen og til deres fælles dialog. Dvs. at multimediecasene virkelig understøttede de studerendes analysearbejde, når de blev anvendt med de påkrævede opgaver,.

Ved bevidst at vælge at guide forberedelsen (i form af opgaver, studenterpræsentationer, essays mv.) og derved bruge en mere udvidet brugssituation skubbes brugen af multimediecases. Fokus flyttes vaek fra den ellers så omtalte casediskussion til analysearbejdet. 
Forberedelsestiden er ikke kun lang for de studerende. Underviseren skal også sætte ressourcer ind, hvad en mere udvidet brugssituation vil kunne kompensere for.

\section{Målgruppen, underviseren og teoriforankring}

Måske ikke overraskende viste det sig nødvendigt at tage hensyn til den heterogene karakter, som målgrupperne ofte har, både når casene udvikles og bruges. Herunder hensyntagen til forskellige faglige kvalifikationer og varierende erfaring med casebaseret undervisning. I mine undersøgelser opererede jeg med to målgrupper, bredt definerede ud fra niveauet i uddannelsen og teori / praksis relation. Den ene gruppe er studerende ved MBA og andre efteruddannelsestilbud til betalende deltidsstuderende med fuldtidsjob og megen arbejdserfaring. Den anden gruppe er fuldtidsstuderende med ingen eller meget lidt arbejdserfaring.

I MBA-gruppen var niveauet højt i selve casediskussionen, højere end generelt hos bachelorer og kandidatstuderende. De var i stand til at relatere til egen erfaring, men disse praktikere inddrog sjældent teori. Det skete i flere, men stadig få tilfælde med bachelorer og kandidater, når en underviser tog initiativ til at involvere fagets teori/modeller i dele af en casediskussion. Teoriinddragelse betød, at de studerende reflekterede over casens indhold og forholdt sig til det på et helt andet niveau end den genfortælling af indhold, de ellers præsenterede. Derved formåede underviseren undertiden i løbet af en casediskussion at højne niveauet ved at inddrage teori. Det var dog tydeligt, at de studerende ikke selv havde gjort dette i deres egen forberedelse. Undtagelsen var de studerende, der forberedte gruppepræsentationer. Her foregik dialogen i forberedelsen, som nævnt, på et meget højt niveau. Der var overskud til at inddrage eksterne ressourcer og teori fra faget.

Dialogen fungerede for mig at se bedst, der hvor underviseren havde gjort de studerendes rolle og analyseperspektiv tydeligt for dem. For studerende uøvet i caseundervisning (og studerende er også uøvede, selv hvis de har været udsat for metoden længe, men ikke er blevet introduceret til dens mål) er det derfor vigtigt, at der fra undervisers side peges på, hvordan casen kan analyseres og hvilke teorier/modeller, der kan anvendes.

Undervisers kompetencer er afgørende. Underviseren kan:

1. Styre casediskussionen i en bestemt retning og kontrollere deltagernes fokus i diskussionen.

2. Forsøge at skabe den rette stemning. Er det fx. ok i en given forsamling at sige noget "vås", noget sjovt, eller stille spørgsmålstegn til diskussionsemnernes vigtighed.

Som støtte for underviseren følger der ofte en undervisningsnote med casen,. Den indeholder gerne spørgsmål, underviseren kan stille de studerende, samt mulige diskussionsemner. Når casen blev anvendt direkte som beskrevet i undervisningsnoten, og med kun få overvejelser om casens karakter i forhold til de faktiske studerende (målgruppen), opstod der problemer. På grund af det store indhold (volumen) i multimediecases er det væsentligt, at underviser overvejer, hvilke emner i casen, det er relevant at inddrage og hvornår. Men det er ligeså relevant, at underviseren påtager sig en mere aktiv loeringsmodererende rolle end bare en diskussionsfaciliterende. Dvs. foruden at planlægge og strukturere diskussionen og emner til diskussion også at fokusere på læringsmål, planlægning, udførelse og opfølgning. Dette perspektiv er også væsentligt, hvis underviser anvender udvidede brugssituationer, hvor multimediecasen bruges i længere forløb og derfor har mere indflydelse på faget $\mathrm{i}$ helhed, dvs. at opfølgning og casens relation til fagets teori/modeller bliver essentielt.

\section{Fastlæggelse af et perspektiv}

Konstruktivistiske undervisningsmodeller ses af mange som interessante og lovende, når de kombineres med IKT. Især hypermediets muligheder lovprises: Nemlig at undervisningsmaterialer anvender forskellige medier, som er linket sammen, således at de stude- 
rende kan konstruere og analysere en struktur og et budskab og ikke kun anvende den på forhånd givne struktur, i et lineært forløb. (Burgoyne \& Mumford 2001, Duffy \& Cunningham 1996, Harper \& Hedberg 1997).

Selv om hyperlinkstrukturen internt i casen gav mulighed for at styrke konstruktion af viden, viste mine undersøgelser, at overraskende få studerende følte, det var nødvendigt at søge uden for casens ramme for at være forberedt. De søgte ikke i litteratur (enten som givet i casen eller i faget) og de søgte ikke videre på internettet efter, hvad konkurrenter gjorde, nyhedsmedier skrev mv. Det var ellers netop intentionen med multimediecasene. De skulle gøre det nemmere for de studerende at overveje andre ressourcer, specielt via casenes eksterne internet-links. I de fag, hvor undervisningen foregik som en traditionel brugssituation, svarede kun halvdelen, at de havde følt det nødvendigt at bruge disse links (varierende holdning fra helt nødvendigt til i nogen grad), mens grupperne, der havde til opgave at lave en gruppepræsentation eller at skrive rapport/essay, alle havde set "uden for casen" i deres forberedelse.

Således oplevede jeg også, at et højt analyse- og evalueringsniveau i dialogen blev nået, da en underviser lod de studerende diskutere, hvorfor en teori ikke kunne anvendes i den givne situation. De studerende fik en opfattelse af praksis som mere kompleks, men at anvendelse af modeller og teori alligevel gav et bedre beslutningsgrundlag. Ligeledes var fx. en gruppes eksamensrapport, som blev lavet på baggrund af materiale fra en multimediecase, på et højt refleksionsniveau med relevant teoriinddragelse. Multimediecases som eksamensmateriale var i øvrigt en interessant og ressourcebesparende måde at anvende dem på. I stedet for at de studerende skulle ud i en virksomhed og først bruge en mængde ressourcer på at skabe kontakt, arrangere interviews mv. var der i casen en adækvat mængde casemateriale til at skrive en rapport til et 10-tal. Det krævede, at gruppen kunne lave velovervejede antagelser (hvor fx. information manglede), kunne søge og inddrage teori og viden fra praksis, og kunne argumentere for deres valg og beslutninger.

Ligesom multimediecases via hyperlinks kan være gode til at understøtte de studerendes egen forståelse af caseindholdet, kan indlejrede undervisningsstrategier fastholde bestemte perspektiver på caseindholdet.

Indlejrede undervisningsstrategier ses i form af forskellige designstrukturer i selve undervisningscasen. Eksempler herpå er:

1. Når multimediecasen overordnet er designet ved brug af enten rådata (såkaldt casemateriale), som de studerende selv skal strukturere og finde hoved og hale i, eller casehistorier (narrativer), med et fastlagt perspektiv/problem.

2. I forhold til måden, der interageres med casen igennem fx. en fastlagt hierarkisk menustruktur eller i et stærkt hyperlinket net af informationer.

3. Når casen gør brug af indlejrede værktøjer som roller og handlingselementer.

Brug af indlejrede undervisningsstrategier havde størst indflydelse på forberedelse af casen, ikke på plenumdiskussionen, i hvert fald ved første øjekast. For selv hvis fx. rollerne ikke blev nævnt synderligt i casediskussionen, blev det tydeligt, at de forskellige perspektiver gjorde, at analysearbejdet fokuserede på forskellige områder. Fx. havde casediskussionen i LEGO-casen, hvor den studerende var en konsulent, ofte et vurderende historisk og fremtidsrettet perspektiv: hvad der historisk var sket i LEGO, blev altid sat i relief til, hvad der så var godt at gøre nu og i fremtiden. Hvorimod diskussionen i Rockwool-casen, hvor den studerende var en ny medarbejder, der havde en ny opgave, primært beskæftigede sig med fremtidige muligheder og ikke så nær så meget bagud på processen, selv om det egentlig var hensigten i forhold til læringsmålet. Men muligheden for at lave en forretningsplan som ny medarbejder satte fokus på fremtiden. (Det viser blot, at cases skal designes med stor hensyntagen til læringsmål.) Diskussionen med ALKA-casen, der havde et mere "objektivt" casemateriale-perspektiv, forløb næsten udelukkende som analyse af den 
historiske proces, altså på hvad der var sket. I de cases fra hele E-case-serien, der indeholdt et ustruktureret casemateriale, var det ofte muligt at lade de studerende anvende et mere udforskende perspektiv og selv finde ind til de interessante budskaber. E-case-seriens cases med casefortællinger/casehistorier, gav mulighed for et mere "prædefineret" perspektiv på casen.

\section{Afslutning}

I denne artikel har jeg kort fokuseret på erfaringer fra caseundervisning samt de muligheder og begrænsninger som casene kan give i undervisningen set i forhold til læringsmål, forløb og ressourcer.

Multimediecases kan, ved at gengive et rigt billede af virkeligheden, virke både motiverende og engagerende på studerende. Generelt set havde casene øget de studerendes interesse $i$ de emner, som de gengav. Det i sig selv er en succes. Motivationen blev yderligere forstærket ved brug af indlejrede værktøjer, inspireret af rollespil og simulationer, samt ikke mindst forskellige undervisningsstrategier, der fastholder caseanalysen i et bestemt perspektiv. Multimediecases tager dog lang tid at forberede, hvilket gør at studerende sjældent har lyst til at forberede sig optimalt, hvis casen kun anvendes i kort tid og ikke vægtes særlig meget i undervisningen. Da det i øvrigt generelt er et kritikpunkt, at caseundervisning sjældent inddrager teori, opnås med multimediecases kun en ringe grad af refleksion i analysearbejdet. Jeg har fundet, at en række værktøjer brugt sammen med multimedicases kan resultere i bedre teori-praksis relation, større refleksion og et højere niveau i dialogen. Værktøjerne og de organisatoriske overvejelser i multimediecases, som jeg har set på her er:

- guided forberedelse (med essays,(eksamens)rapporter, opgaver, præsentationer mv.),

- udvidet brugssituation (det at inddrage multimediecases i længere tidsmæssige forløb),

- indlejrede værktøjer (roller og handlingsorienterede elementer, som rapporter mv.),

- studenternes rolle (faglige kompetencer og erfaring med caseundervisning),

- $\quad$ underviserens rolle (både diskussionsfaciliterende og lceringsmodererende, samt kompetence i caseundervisning),

- indlejrede undervisningsstrategier (casematerialer, casehistorier/narrativer, interaktions- og navigeringsstruktur, pædagogiske værktøjer mv.).

Emnerne, jeg har fremført, forsøger at pege på en række områder, som måske kan inspirere ved fremtidig udvikling og brug af cases. Og selvom det at gøre undervisningscases til multimediecases (frem for papirbaserede) ikke i sig selv er en forbedring af casebaseret undervisning, så kan en gennemtænkning af den læringsmæssige og pædagogiske ramme om en multimediecase fremme kvaliteten af læringsprocessen.

Det kunne være interessant at høre, om andre har gjort lignende eller helt modsatrettede erfaringer!

\section{Litteratur}

Ball; Linden and Thomas Ormerod. "Putting ethnography to work: The case for a cognitive ethnography of design". International Journal of Human-Computer Studies, 53 (1), (2000): 147-168.

Bloom; Benjamin S. (editor) et al. Taxonomy of Educational Objectives - The Classification of Educational Goals. Handbook I, Cognitive Domain. New York: Longman, 1956 
Burgoyne; John \& Alan Mumford. Learning from the case method, a report to the European Case Clearing House. Lancaster, UK: Department of Management Learning, Lancaster University Management School, 2001

Duffy; Thomas \& Donald Cunningham. "Constructivism: Implications for the Design and Delivery of Instruction", Handbook of Research for Educational Communications and Technology. Ed. D.H. Jonassen. New York, NY: Macmillan Library Reference, 1996.

Harper; Barry \& John Hedberg. "Creating Motivating Interactive Learning Environments: a Constructivist View" ASCILITE 97 conference proceedings, Australian Society for Computers in Learning in Tertiary Education (1997): 11-31.

Heath; John. Teaching and writing Case Studies - a practical guide. Bedford, UK: The European Case Clearing House, Cranfield University, 1998

Lee; Virginia. "Creating a Blueprint for the Constructivist Classroom". The National Teaching and Learning Forum - NTLF. Vol 8 No. 4 (1999):1-6.

Nielsen; Janni et al. "Learning happens -rethinking video analysis". Learning in Virtual Environments. Eds. Lone Dirckinck-Holmfeld \& Bo Fibiger. Frederiksberg: Samfundslitteratur, 2002. 310-339.

Orngreen; Rikke. Multimedia Teaching Cases, Ph.D.-series 27. Frederiksberg: Samfundslitteratur: 2002 